\title{
The Ontological of State of Law of Pancasila as The Basis of Welfare State in Indonesia
}

\author{
I Nyoman Bagiastra ${ }^{1}$
}

${ }^{1}$ Faculty of Law Udayana University, E-mail: nyoman_bagiastra@unud.ac.id

\begin{tabular}{l}
\hline Info Artikel \\
\hline Masuk: $29^{\text {th }}$ October 2020 \\
Diterima: $21^{\text {st }}$ December 2020 \\
Terbit: $31^{\text {st }}$ December 2020 \\
Keywords: \\
Pancasila; Welfare; Indonesia \\
Corresponding Author: \\
I Nyoman Bagiastra, e-mail : \\
nyoman_bagiastra@unud.ac.id \\
DOI: \\
10.24843/JMHU.2020.v09.i04. \\
p03
\end{tabular}

\begin{abstract}
The rule of law as stated in the Constitution of the Republic of Indonesia, namely article 1 Section 3 of the 1945 Constitution which states explicitly that the State of the Republic of Indonesia is a rule of law, of course, has juridical consequences that must be accounted for in the practice of community life, nation, and state. By claiming to be a rule of law, Indonesia must fulfill and realize all the requirements and principles contained in a rule of law, namely the state has the obligation and provides legal certainty for protection to realize the welfare of its citizens. The research method used is normative legal research. the welfare state is briefly described as a series of public policies and state activities in integrating economic policies and social policies for the sake of achieving prosperity.
\end{abstract}

\section{Introduction}

Law may regulate people equally, but people are not equal to structurally. ${ }^{1}$ That is a fact in the socio juridical reality that exists in various people's lives in this world, especially in a third world country like Indonesia where there are still many social inequalities which often feel so alarming. ${ }^{2}$

The law is the protection of human interests because the law is a method whose function is to protect human interests. ${ }^{3}$ Actually law is an awareness of the values contained in humans, about existing laws or about laws that are expected to exist, in fact, what is emphasized is the values about the function of the law and not an assessment of the law. 4

\footnotetext{
${ }^{1}$ Nurcahyo, E. Pancasila Sebagai Volkgeist: Pedoman Penegak Hukum dalam Mewujudkan Integritas Diri dan Keadilan. Jurnal Magister Hukum Udayana (Udayana Master Law Journal), 9(1), 142-152. h. 3. Doi: https:// doi.org/10.24843/JMHU.2020.v09.i01.p10

2 Kurniawan, E. J. A. (2012). Pluralisme hukum dan urgensi kajian socio-legal menuju studi dan pengembangan hukum yang berkeadilan sosial. Yuridika, 27(1), 17-34. h. 3. Doi: http://dx.doi.org/10.20473/ydk.v27i1.284

${ }^{3}$ Cahyadi, A. (2017). HUKUM RAKYAT a'La Friedrich Karl von Savigny. Jurnal Hukum \& Pembangunan, 35(4), 386-406. h.4. Doi: http:// dx.doi.org/10.21143/jhp.vol35.no4.1466

4 Ahmad, I. (2018). Rencana Dan Strategi Peningkatan Kesadaran Hukum Masyarakat. Gorontalo Law Review, 1(1), 15-24. h. 3. Doi: https://doi.org/10.32662/golrev.v1i1.94
} 
I Dewa Gede Palguna expressed his understanding of the concept of the rule of law. First, the concept of rule of law covers the issue of the source or basis of the legitimacy of government action, namely the existence of people's unity (the popular idea of consent). Second: the concept of rule of law also covers the issue of good governance structures, namely that governmental power (in a broad sense) which includes legislative, executive, and judicial powers cannot be in one hand but must be separated (the idea of separation of powers) specifically for power the judiciary, apart from having to be separated, it also has independence (independence of the judiciary idea). Third, the concept of rule of law, includes complaints about individual rights that cannot be taken or violated by the government or by individuals (the idea of respecting and protecting human rights). ${ }^{5}$

Indonesian society has a very high background and level of diversity based on economic, cultural, social, and so on. Social groups in Indonesia, whether based on place of residence, ethnicity, interests, and others, should be able to realize the integralists ideals of the Indonesian nation. This integrality ideal is contained in Pancasila. ${ }^{6}$

As a rule of law, it is proper that the principles of a rule of law must be respected and upheld. ${ }^{7}$ One of them is by protecting access to justice for the community. For example, by the constitutional mandate of Article $28 \mathrm{H}$ paragraph (1) which reads, everyone has the right to live in physical and mental well-being, to have a place to live, and to have a good and healthy living environment and the right to obtain health services. Meanwhile, Article 34 paragraph (1) states that the poor and neglected children are cared for by the State, and paragraph (3) states that the State is responsible for the provision of proper health service facilities and public service facilities. Consequently, in terms of human rights which are fundamental as stated in the constitution of the Republic of Indonesia, the state is obliged to provide this

Looking back, the basic idea regarding the concept of a constitutional state in Indonesia expressly states in the 1945 Constitution, of course it cannot be far from the existence of Pancasila as the basis of the state and the source of all sources of law and the soul of the Indonesian nation, it can be said that Pancasila animates all life. Indonesian rule of law. 8

It is said that because Pancasila is the philosophy of the Indonesian people and that philosophy is a thought that includes "de zin van Wereld en leven" (the meaning of the world and life). ${ }^{9}$ Likewise with the philosophy of Pancasila, the philosophy of

${ }^{5}$ I Dewa Gede Palguna, (2013), Pengaduan Konstitusional (Constitutional Complaint) Upaya Hukum Terhadap Pelanggaran Hak-hak Konstitusional Warga Negara, Cet. Pertama, Sinar Grafika, Jakarta, h. 79.

6 Siregar, C. (2014). Pancasila, Keadilan Sosial, dan Persatuan Indonesia. Humaniora, 5(1), $107-$ 112. h. 4. Doi: https://doi.org/10.21512/humaniora.v5i1.2988

${ }^{7}$ Latipulhayat, A. (2015). Khazanah: Friedrich Karl Von Savigny. Padjadjaran Journal of Law, 2(1). h. 5. Doi: https://doi.org/10.22304/pjih.v2n1.a12

8 Juwana, H. (2006). Penegakan Hukum dalam Kajian Law and Development: Problem dan Fundamen bagi Solusi di Indonesia. Indonesian Journal of International Law, 3(2), h. 3. Doi: http://dx.doi.org/10.17304/ijil.vol3.2.398

9 Samekto, F.X. Adji. (2013). Relasi Hukum dengan Kekuasaan: Melihat Hukum dalam Perspektif Realitas. Jurnal Dinamika Hukum 13(1), h. 2. Doi: http://dx.doi.org/10.20884/1.jdh.2013.13.1.157 
Pancasila has been accepted and as proof of the philosophy of the Indonesian people today that does not need to be proven anymore. Therefore, all activities and actions in the development of the state and society of Indonesia must be rooted in Pancacila. In the fields of law, health, education, economics, arts, state affairs and most importantly in all fields.

The development of a national legal system (Indonesian legal system), must start from a national legal culture, which will affect the strength and authority of the enactment and stipulation of various national legal principles.

The condition of the Indonesian nation today is very concerning because Indonesians in the 21st century tend to be "egotistical" and individualism caused by changes in technology, material and social life which is more advanced and open due to the speed of communication between nations globally, without being felt it also causes a shift, from national identity to international identity on the one hand (traditional society). This is a characteristic that society is experiencing a crisis, especially in a moral crisis that counts with moral decadence, greed, materialism, hedonism, non-ethics in politics, tendencies of authoritarianism and spiritual impoverishment. The crisis has an impact on social life which in the end can have an impact on a legal crisis, a crisis of trust, a crisis in the legitimacy of power and ultimately an economic crisis.

The legal ideals of the Indonesian nation are rooted in Pancasila, which the founding fathers of the Republic of Indonesia set as a philosophical foundation in arranging the framework and basic structure of the state organization formulated in the 1945 Constitution. Humans and God, the relationship between humans and fellow humans, and the relationship between humans and the universe, which is based on beliefs about the place of humans in society and the universe.

The founders of the Indonesian nation were brilliantly able to agree on the right choice of the basis of the state in accordance with the national character, very original, to become a modern state with religious character, neither as a secular state nor as a religious state. The formulation of the conception is completely oriented and adapted to the character of the nation. They were not only able to get rid of the influence of the patrimonial state idea, but also were able to creatively formulate various political thoughts that were developing at that time according to the needs of the modern future of the nation's children.

Thus, it can be concluded that the rule of law concept adopted and applied in Indonesia is not a rule of law concept like the rechtsstaat concept in countries that adhere to the civil law legal system or the concept of the rule of law in countries that adhere to the common law system, but rather adhere to and apply the concept of a rule of law in accordance with the conditions and spirit of the Indonesian nation, namely the concept of the rule of law of Pancasila. ${ }^{10}$

This is because the concept of the rule of law Pancasila was born not because of the resistance to absolutism by the rulers or kings (as the background for the emergence of the idea of rechtsstaat and the rule of law), but because of the desire of the Indonesian nation to be free from imperialism and colonialism by the colonialists. Netherlands.

${ }_{10}$ Mawardi, Didiek R. (2015). Fungsi Hukum dalam Kehidupan Masyarakat. Jurnal MasalahMasalah Hukum 44(3), h. 6. Doi: https:/ / doi.org/10.14710/mmh.44.3.2015.275-283 
Indonesia actually does not adhere to the concept of rechtsstaat or the concept of the rule of law purely, but rather forms a new rule of law concept, namely the Pancasila Law State, which is a crystallization of the views and philosophy of life that are conditional on the values and ethics and morals of the Indonesian nation, as stated in the preamble. The 1945 Constitution and implied in the articles of the 1945 Constitution.

\section{Research Method}

The research method used is normative legal research. Normative legal research examines laws that are conceptualized as norms or rules that apply in society and examines the behavior of each person. Normative legal research is doctrinal legal research, also known as library research or document study.

\section{Results and Discussion}

According to Scheltema as quoted by B. Arief Sidharta, a view on the elements and principles of a rule of law has been formulated, which includes 5 things as follows: (1) Recognition, respect and protection human rights rooted in respect for dignity human; (2) The principle of legal certainty, which consists of from: legality, constitutionality and rule of law principles; the principle of non-retroactivity; the principle of free trial; non-liquet principle-judge may not reject a case; the principle of government based on

law; and the existence of the formulation of human rights in the constitution; (3) Similia Similibus principle-the principle of equality, which consists of: equal position before the law, and treat that the same for all citizens; (4) The principle of democracy, that every people have the same opportunity to influence government action, manifested through a representation system; (5) Government and Government Officials carry out service functions public.

Inspired by the concept of a western rule of law, in this case rechtstaat, the 1945 Constitution calls for rechtstaat elements and rule of law to be part of the principles of the Indonesian rule of law. ${ }^{11}$ Notonegoro as quoted by Bernard Arief Sidharta provides an understanding of Pancasila as the principle or "guiding principle" of the state in Indonesia. As the principle of the state, Pancasila can be said to be the foundations of the State Idiology. Juridically, Pancasila is a fundamental principle of the state. ${ }^{12}$ This can be seen from the philosophical statement put forward by Notonagoro that:

"Talking about Pancasila, we should place ourselves as fellow citizens of the nation, fellow brothers and sisters, sons of our motherland, Indonesia. We should always remember the equality of our natural position and the same nature of our nature. We are born as descendants of one ancestor, we have unity blood, by being born on the earth of Indonesia, we have a unity of place of birth and place of residence. We have a unity of source of life, where we live together,

11 Erwinsyahbana, T. (2012). Sistem hukum perkawinan pada Negara hukum berdasarkan pancasila. jurnal ilmu hukum, 3(1), h. 173. Doi: http:/ /dx.doi.org/10.30652/jih.v3i01.1027

12 Arief Sidharta, (2009), Revisi Pemikiran Prof. Socdiman Kartohadiprodjo tentang Pancasila terkaitan dengan Pengembangan Sistcm Hukum National, Dies Natalis ke 51 Fakultas Hukum Universitas Katolik Parahyangan, Bandung, h. 20. 
where we together get everything we need for our life, in where we associate and cooperate with each other, where we have shared a common fate and history, where after the Proclamation of Independence we have a determination to arrange a life together in a united, independent, just and prosperous country, for ourselves and for our children. we have come to the end of time. Our country because of its absolute monodualist humanity, ma'am it is a liberal state, not a mere power or dictatorial state and not a materialist state. Our country is a country consisting of individuals living together, both in birth and in mysticism, both of whom have individual needs and interests as well as common needs and interests, both of which are carried out not to interfere with one another, but in cooperation. Our country is what is called a state of cultural law."

Since one of the most important elements in a constitutional state is the attachment of state organs to laws and laws, statutory regulations or in a broader context are law, must be clearly formulated, not multi-interpretative, and capable of realizing legal certainty. This is in accordance with the opinion of Arif Hidayat, who said that in general the concept of a rule of law in principle includes four basic demands, namely: (1) legal certainty; (2) the law applies equally to all residents; (3) the existence of democratic legitimacy in law making; and (4) upholding human dignity.

It should be noted that the rule of law of Pancasila is a prismatic rule of law concept. Namely the concept of the rule of law Pancasila which combines the elements contained in different concepts of the rule of law (the rule of law or rechtsstaat) into one unified concept (the Indonesian rule of law) whose implementation is adjusted to the demands of the times (eclecticism).

The Indonesian rule of law which is based on Pancasila and the 1945 Constitution takes the prismatic concept or the integrated legal concept of the two concepts so that the "legal certainty" contained in the rechtstaat can be combined with the "justice" principle contained in the Rule of Law. Indonesia did not choose one of them but included the good elements of both. Thus, the concept of a rule of law in Indonesia, namely the concept of a rule of law, Pancasila, has its own characteristics that distinguish it from other concepts of rule of law. In addition, related to the prismatic concept of Pancasila, these two opinions and desires bring together. The Pancasila state is not a religious state, nor is it an anti-religious state, but a divine state that maintains noble human character and upholds the noble moral ideals of the people. The Islamic group was initially unhappy with the proposal to build an independent Indonesia on the basis of Pancasila. But finally accepted it too. They reject the anti-religious state, but can accept the Godly Pancasila state, while the national groups reject the religious state, but can accept the divine state.

Prismatic law which integrates the elements contained in various laws (legal systems) so as to form a new and complete law characterized by The rule of law of Pancasila, Soehino stated the following: 13

${ }^{13}$ Soehino,(1985), Hukum Tata Negara NKRI Berdasarkan Pancasila dan UUD 1945 adalah Negara Hukum, Liberty, Yogyakarta, h. 32. 
1. The rule of law of Pancasila is a family state.

In a family state, there is recognition of individual rights (including property rights) or human rights but still prioritizing national interests (common interests) over the interests of the individual. On the one hand, this is in line with the social values of the Indonesian society which are community in nature, but on the other hand, it is also in line with the shift of Indonesian society towards a modern society which is patembayan in nature. This is in stark contrast to the concept of a Western rule of law which emphasizes the widest possible extent of individual freedom, at the same time it is just a departure from the concept of a socialismcommunism legal state that emphasizes communal interests or common interests. In the constitutional state of Pancasila, efforts are made to achieve a harmony and balance between individual interests and national interests (society) by giving the state the possibility to intervene as long as necessary for the creation of an order for social, national and state life in accordance with the principles of Pancasila.

2. The rule of law of Pancasila is a state of law with certainty and justice.

With its prismatic nature, the concept of the rule of law Pancasila in legal activities, both in the process of formation and enforcement, is carried out by combining elements, both contained in the concept of Rechtsstaat and the concept of the Rule of Law, namely by combining the principle of legal certainty with the principle of justice, so that creates a prerequisite that legal certainty must e upheld in order to uphold justice in society in accordance with the principles of Pancasila.

3. The rule of law of Pancasila is a religious nation state.

By looking at the relationship between the state and religion, the concept of the rule of law Pancasila does not embrace secularism but is also not a religious state as in theocracy and in the concept of Islamic Nomocracy. The concept of the rule of law Pancasila is a concept of a godly state. Belief in here means that the life of society, as a nation and as a state in Indonesia must be based on belief in the one and only Godhead, thereby opening a freedom for citizens to embrace a religion and belief according to their respective beliefs. The logical consequence of this prismatic choice is that atheism and communism are also prohibited because they have put aside the belief in God Almighty;

4. The rule of law of Pancasila integrates law as a means of changesociety and law as a mirror of society's culture.

By combining these two concepts, the rule of law of Pancasila is strived to maintain and reflect the values that live in society (living law or local wisdom) as well as positivating the living law or local wisdom to encourage and direct the community to progress in accordance with the principles -Principles of Pancasila.

The concept of a rule of law, Pancasila, is a rule of law concept developed and implemented in Indonesia. The concept of the Indonesian rule of law must be based on the Pancasila legal system. It can also be said that the concept of a constitutional state in Indonesia has a distinctive feature in the philosophy of the Indonesian nation and 
state, namely the philosophy of Pancasila. The concept of the constitutional state of Pancasila is also characterized or based on the identity and characteristics contained in the Pancasila philosophy, namely: God Almighty, kinship, mutual cooperation and harmony. The existence of Pancasila as a state philosophy or state ideals (staatsidee) which functions as a philosophical gronslag and common platforms or sawa sentences among citizens in the context of state life in the first agreement that supports constitutionalism shows the essence of Pancasila as an open ideology. ${ }^{14}$

The national goal of the State as the highest organization of the Indonesian nation which is organized based on Pancasila can be seen below:

"Pancasila is the guide for the national law politics in various fields. The principle of" God in One God "becomes the basis for the Political Law based on religious morals; the principle of" Humanity. Fair and Civilized "becomes the basis for Political Law that respects and protects human rights nondiscriminatory; the principle of "Indonesian Unity" becomes the basis for Political Law to unite all elements of the nation with their various primordial ties; ) and the principle of "Social Justice for All Indonesian People" becomes the basis of legal politics in a socially just society so that those who are socially and economically weak are not arbitrarily oppressed by those who are strong".

In relation to the rule of law concept adopted by the Indonesian nation, the characteristics of the rule of law Pancasila are as follows:

a) The rule of law

All uses of power must always have a legal basis and be carried out within the framework of the limits established by law, a fortiori for the use of public power. Thus, in a Pancasila state, the desired government is a government based on and by law (rule of law and rule by law).

b) Democratic country.

All state activities are always open to the participation of the whole community, in which the exercise of authority and the use of public power must be accountable to the public and must always be open to rational assessment by all parties within the framework of the prevailing values and legal order.

c) Organization of all people.

The whole society organizes itself rationally to be in together and endeavored, within the framework of and through the prevailing legal system, to create physical and mental well-being for all people by always referring to the values of human dignity and God Almighty. In the Pancasila state conception, the state and government are more of a coordination between various centers of rational decision-making which are based on the rational principles of efficiency, rationality-reasonableness, rationality with rules and principles of value rationality, rather than merely an organization of power solely.

\footnotetext{
${ }^{14}$ Tcguh Prasetyo dan Abdul Halim Barkatullah, (2012), Filsafat, Teori dan llmu Hukum: Pemikiran Menuju Masyarakat Yang Berkeadilan dan Bermartabat, PT. RajaGralindo Persada, Jakarta, h. 367.
} 
In essence, the constitutional state of Pancasila has 8 (eight) main characteristics as follows:

1. There is a close relationship between religion and the state.

2. Relying on the Supreme Lordship.

3. Religious freedom in a positive sense.

4. Atheism is not justified and communism is prohibited.

5. The principle of kinship and harmony.

6. The constitutional system.

7. Equality in law.

8. Fair trial

It is necessary to know that the rule of law of Pancasila provides a high and noble position for human potential and dignity. Therefore, the teachings regarding respect and protection of human rights based on the rule of law of Pancasila must be imbued with and based on normative principles of religious-theism. The normative principle of theism-religious in question can be described as follows:

a) Whereas human rights are a gift and a gift from the Creator (precepts I and II) as well as a mandate to be enjoyed and grateful for by mankind.

b) Whereas upholding human rights is always based on the principle of balance with human obligations. This means that human rights will be upheld only because (mankind) fulfills human obligations as the mandate of the Creator, as the moral integrity of human dignity.

c) Human obligations based on the Pancasila philosophy include the following:

a. Humans are obliged to acknowledge that the source (human rights: life, liberty, property) is the Almighty God (precepts I) who bestows and mandates the potential for physical and spiritual personality as dignity (noble) for humanity.

b. Humans are obliged to recognize and accept the sovereignty of the Creatorover the universe, including the fate and destiny of humans.

c. Humans are obliged to thank and be wise to the Creator, for the grace and mandate entrusted to him (human personality).

What is the central point of the Indonesian State is the harmonious relationship between the government and the people based on the principle of harmony. This is what distinguishes the concept of the rule of law Pancasila with the rule of law and rechtsstaat. In the rule of law and rechtsstaat, the central point is the recognition and protection of human rights.

Development of elements of the rule of law, Pancasila. The elements in question are as follows:

1) Harmony between the government and the people is based on principlesharmony.

2) Proportional functional relationship between powerscountry.

3) The principle of deliberative and judicial dispute resolutionis the last means.

4) Balance between rights and obligations. 
To clarify the direction and goals to be achieved, namely moving from the national goal of the Indonesian state, namely the welfare of the nation. The concept of the Welfare State was preceded by the concept of the Night Watch State (Nachtwachterstaat). In the concept of the Night Guard State, the government is only allowed to enter the security area and not enter the political and economic area, in accordance with the argument of "laissez-faire laissezaller" or The Basic Idea of the Welfare State as put forward by Watts, Dalton and Smith, has existed since the 18th century when Jeremy Bentham $(1748-1832)^{15}$ explained the idea that the government has the responsibility to guarantee the greatest happiness (Wellfare) of the greatest number of their citizens, it means that the government has an obligation to make as many people happy as possible.

The concept of the Welfare State was born in the XIX century as a reaction to the weaknesses of classical liberalism and capitalism as well as a reaction to the teachings of the "night watchman state" (nachtwachtersstaat) which idealizes the principle of the best government is that which regulates as little as possible (the best government is the least government) .

The Welfare State is actually a state or government that is not alone as the guardian of security or public order, but bears the main responsibility for realizing social justice, general welfare and the greatest prosperity of the people.

The welfare state is associated with the process of distributing existing resources to the public, either in cash or in some form (cash benefits or benefits in kind). The concept of welfare is also closely related to socio-economic policies that seek to realize the welfare of the people in general. Some of the areas most closely watched for in welfare policy are issues of education, health and employment.

Economic development carried out by the welfare state must correlate with the benefit and prosperity of the people. This principle is the main task that must be realized in the welfare state. According to him, there are two things that are directly related to economic development efforts, first, the realization of a welfare state that is separate from economic development efforts. As has been stated, economic development must make society more prosperous, not the other way around. Second, the goal of the realization of the welfare state is not only for reasons of territory (equality), but also for the sake of equality, which does not conflict with the objectives of efficiency in the economy. These two things are part of the goals of the welfare state.

Understanding the welfare state must begin with interpreting that "People live in society, and have obligations to each other." After that, then understand the context of "Welfare is obtained and maintained through social action." So, understanding the welfare state theory must first understand the nature and extent of the nature of the existence of society, the meaning of society, the goals of society, and the values that grow in society (society).

\footnotetext{
${ }^{15}$ Bentham uses the term utility (utility) in describing the concept of happiness or well-being. On the basis of his principle of utility Bentham says that anything that can bring extra happiness is a good thing. Bentham also argues that the government has an obligation to make as many people happy as possible, and it is for these ideas that Bentham is recognized as the Father of Welfare State.
} 
In the concept of the welfare state, the idea that the government is prohibited from intervening in the affairs of citizens gradually turned into the idea that the government must intervene and be responsible for the people's welfare, and therefore it must be proactive in regulating economic and social life.

If the intervention is linked to the main objectives of the welfare state, among others;

1. Controlling and using social and economic resources for the public interest

2. Ensure a fair and equitable distribution of wealth

3. Reducing poverty

4. Providing subsidies for basic social services for disadvantage people.

5. Providing social insurance (health and education) for the poor.

6. Provide social protection for every citizen.

In Indonesia, which in fact dominantly strives by adhering to the constitutional state of Pancasila, in fact it is highly correlated in realizing a welfare state. The rule of law of Pancasila aims to maintain and develop "human character and moral ideals of the people based on the one and only Godhead". The implementation of this protection is carried out in an effort to realize the following things, namely order and order that gives rise to predictability, peaceful peace, justice (distributive, commutative, indicative, protective), welfare and social justice, fostering high morals based on the one and only God.

\section{Conclusion}

It can be said that the goal of the Rule of Law of Pancasila is to create prosperous and humane social conditions in such a way as to enable social processes to take place naturally. In Indonesia, few terms are used to properly interpret the welfare state. In short, the welfare state is briefly described as a series of public policies and state activities in integrating economic policies and social policies for the sake of achieving prosperity. Constitutionally, the Welfare State of Indonesia is contained in the 4th paragraph of the Preamble of the 1945 Constitution, Article 27 paragraph (2), Article 33, and Article 34. The form of state or government interference in realizing a 'welfare state based on the state law of Pancasila' something that must be done as a mechanism for the redistribution of wealth in an effort to improve the welfare of its people.

\section{Reference}

$\underline{\text { Books }}$

Basah, S. (1992), Perlindungan Hukum Terhadap Sikap-Tindak Administrasi Negara, Bandung: PT. Alumni.

Palguna, I Dewa Gede. (2013), Pengaduan Konstitusional (Constitutional Complaint) Upaya Hukum Terhadap Pelanggaran Hak-hak Konstitusional Warga Negara, Cet. Pertama, Jakarta: Sinar Grafika,

Sidharta, Arief. (2009), Revisi Pemikiran Prof. Socdiman Kartohadiprodjo tentang Pancasila terkaitan dengan Pengembangan Sistcm Hukum National, Dies Natalis ke 51 , Bandung: Fakultas Hukum Universitas Katolik Parahyangan,

Notonagoro, (1975), Pancasila Secara llmiah Populer, Jakarta: Pantjuran Tujuh, 
Prasetyo, T., \& Barkatullah, A. H. (2012). Filsafat, Teori, dan Ilmu Hukum Pemikiran Menuju Masyarakat yang Berkeadilan dan Bermartabat. Jakarta: Raja Grafindo Persada.

\section{Journal}

Arief Sidharta, B. (2004). Kajian Kefilsafatan tentang Negara Hukum. Jentera: Jurnal Hukum. Pusat Studi Hukum dan Kebijakan Indonesia (PSHK). Edisi, 3.

Nurcahyo, E. Pancasila Sebagai Volkgeist: Pedoman Penegak Hukum dalam Mewujudkan Integritas Diri dan Keadilan. Jurnal Magister Hukum Udayana (Udayana Master Law Journal), 9(1), 142-152.

Kurniawan, E. J. A. (2012). Pluralisme hukum dan urgensi kajian socio-legal menuju studi dan pengembangan hukum yang berkeadilan sosial. Yuridika, 27(1), 17-34.

Cahyadi, A. (2017). Hukum Rakyat a'La Friedrich Karl von Savigny. Jurnal Hukum \& Pembangunan, 35(4), 386-406.

Ahmad, I. (2018). Rencana dan Strategi Peningkatan Kesadaran Hukum Masyarakat. Gorontalo Law Review, 1(1), 15-24.

Siregar, C. (2014). Pancasila, Keadilan Sosial, dan Persatuan Indonesia. Humaniora, $5(1), 107-112$.

Latipulhayat, A. (2015). Khazanah: Friedrich Karl Von Savigny. Padjadjaran Journal of Law, 2(1)., 197-208.

Juwana, H. (2006). Penegakan Hukum dalam Kajian Law and Development: Problem dan Fundamen bagi Solusi di Indonesia. Indonesian Journal of International Law, 3(2), 212-241.

Samekto, F.X. Adji. (2013). Relasi Hukum dengan Kekuasaan: Melihat Hukum dalam Perspektif Realitas. Jurnal Dinamika Hukum 13(1), 89-98.

Mawardi, Didiek R. (2015). Fungsi Hukum dalam Kehidupan Masyarakat. Jurnal Masalah-Masalah Hukum 44(3), 6. 275-283.

Erwinsyahbana, T. (2012). Sistem hukum perkawinan pada Negara hukum berdasarkan pancasila. jurnal ilmu hukum, 3(1).

Yusuf, A. W. (2015). Law and Justice (Hukum dan Keadilan). PADJADJARAN Jurnal Ilmu Hukum, 2(1). 1-13.

\section{Website}

Arif Hidayat, (2010). "Kepastian Hukum Harus Sejalan dengan Rasa Keadilan”, Antara News, diakses pada https://www.antaranews.com/berita/172595/kepastianhukum-harus-sejalan-dengan-rasa-keadilan 